\title{
Bioluminescent Binding Microassay Using Aptamers as Biospecific Elements
}

\author{
Ludmila A. Frank*a,b, Eugenia E. Bashmakova ${ }^{a}$, \\ Natalia S. Goncharova ${ }^{a, b}$ and Vasilisa V. Krasitskaya ${ }^{a}$ \\ ${ }^{a}$ Institute of Biophysics SB RAS \\ Federal Research Center "Krasnoyarsk Science Center SB RAS" \\ 50/50 Akademgorodok, Krasnoyarsk, 660036, Russia \\ ${ }^{b}$ Siberian Federal University \\ 79 Svobodny, Krasnoyarsk, 660041, Russia
}

Received 12.02.2019, received in revised form 21.05.2019, accepted 04.06.2019

High specificity is an important requirement for an analytical system aimed at identifying a specific molecular target. Traditionally, antibodies, haptens and some other molecules are used for this purpose. Recently, aptamers were proposed as biospecific elements. Aptamers are short singlestranded oligonucleotides with a unique spatial structure that enables them to recognize target molecules and bind to them. Aptamers are obtained from synthetic random DNA(RNA)-libraries, a pool of oligonucleotides of the same length with different base sequences (10 14 -10 $10^{15}$ variants), by selecting the oligonucleotides that are capable of specific binding to a given target. Aptamers are stable molecules with high affinity and specificity; they can be developed for any target, including toxic and nonimmunogenic ones; and they can be easily synthesized chemically. Due to these useful qualities, aptamers are often considered to be an alternative to antibodies. This paper describes the use of aptamer sensors and a highly sensitive bioluminescent reporter, the $\mathrm{Ca}^{2+}$-regulated photoprotein obelin, for the detection of diagnostically important targets in the blood of patients. Additionally, obelin was successfully applied as a reporter in the process of obtaining aptamers. A proposed bioluminescent solid-phase assay enables the enrichment of the oligonucleotide library with target-specific oligonucleotides to be monitored rapidly, the affinity of individual aptamers and their shortened variants to be evaluated and the relative position of the aptamers on the target molecule to be determined. The results of the studies reviewed in this paper open promising avenues for developing analytical systems that include highly specific aptamer sensing, as well as highly sensitive detection based on bioluminescent reporter proteins.

Keywords: aptamers, $\mathrm{Ca}^{2+}{ }_{-}$-regulated photoprotein obelin, bioluminescent microassay.

(C) Siberian Federal University. All rights reserved

This work is licensed under a Creative Commons Attribution-NonCommercial 4.0 International License (CC BY-NC 4.0).

* Corresponding author E-mail address: 1frank@yandex.ru

ORCID: 0000-0003-4462-1944 (Frank L.A.); 0000-0002-8951-8599 (Bashmakova E.E.); 0000-0001-7018-2581 (Krasitskaya V.V.) 


\title{
Биолюминесцентный молекулярный микроанализ на основе аптамерной сенсорики
}

\author{
Л.А. Франк ${ }^{\mathrm{a}, \boldsymbol{0}}$, Е.Е. Башмакова ${ }^{a}$, \\ Н.С. Гончарова ${ }^{\text {a, }}$, В.В. Красицкая ${ }^{a}$ \\ ${ }^{a}$ Институт биофизики СО РАН \\ ФИЦ «Красноярский научный иентр СО РАН» \\ Россия, 660036, Красноярск, Академгородок, 50/50 \\ ${ }^{6}$ Сибирский федеральный университет \\ Россия, 660041, Красноярск, пр. Свободный, 79
}

Важнейтим качеством аналитической системы, направленной на выявление определенной молекулярной митени, считается высокая специфичность. Традиционно для этого используют антитела, гаптены и пр. Сравнительно недавно в качестве биоспециффических элементов были предложены аптамеры - короткие одноцепочечные олигонуклеотиды, обладающие уникальной пространственной структурой, благодаря чему способные "распознавать» и специфическим образом связываться с молекулами-мишенями. Аптамеры получают из синтетических рандомных ДНК(РНК)-библиотек, совокупности олигонуклеотидов одинаковой длины с разной последовательностью оснований (1014-1015 вариантов), путем отбора тех, что способны специфическим образом связываться с данной мишенью. Аптамеры стабильны, обладают высокой аффинностью и специфичностью, их можно получать к любым мишеням, в том числе неиммуногенным и токсичным, их легко синтезируют химически. Благодаря этим преимуществам аптамеры часто рассматривают как альтернативу антителам. В данной работе описаны случаи применения аптамерной сенсорики и высокочувствительного биолюминесиентного репортера - $С a^{2+}$-регулируемого фотопротеина обелина для выявления диагностически важных мишеней в крови пациентов. Этот же репортер предложено использовать при получении новых аптамеров. Разработанный оригинальный биолюминесцентный твердофазный анализ позволяет быстро отслеживать процесс обогащения синтетических библиотек специфичными к данной митени олигонуклеотидами, оценивать аффинность полученных индивидуальных аптамеров и их укороченных вариантов, а также взаимное расположение аптамеров на молекуле-мишени. Результаты рассмотренных в работе исследований показывают перспективность разработки аналитических систем, включающих, с одной стороны, высокоспецифичную аптамерную сенсорику, а с другой высокочувствительную детекцию на основе биолюминесцентных репортерных белков.

Ключевые слова: аптамеры, $\mathrm{Ca}^{2+}$-регулируемый фотопротеин обелин, биолюминесиентный микроанализ. 


\section{Introduction}

The process of binding analysis includes recognition of the target with the formation of a specific complex, the appearance of which is detected by the various reporters (Fig. 1). Some examples of reporters are radioisotopes, fluorophore molecules, and enzymes that generate visually detectable (or measurable) products (e.g., color and light).

In this study, we discuss a bioluminescent reporter, that is, an enzyme generating a quantum of visible light as one of the products of the reaction it catalyzes.

The common name for such enzymes is luciferase, and their substrates are called luciferins. At present, a large variety of luciferases have been characterized, each of which catalyzes the oxidation of the corresponding luciferin. A specific kind of luciferases are the $\mathrm{Ca}^{2+}$-regulated photoproteins of marine coelenterates, particularly obelin of the hydroid Obelia longissima. Obelin is a stable noncovalent complex of a singlechain polypeptide (apo-obelin) and preoxidized luciferin, 2-hydroperoxycoelenterazine. Obelin bioluminescence is triggered by $\mathrm{Ca}^{2+}$, which is why it is referred to as a ' $\mathrm{Ca}^{2+}$-regulated' protein. Obelin has been successfully used as a reporter in bioluminescent binding assays for determining different diagnostically important targets, including hormones, oncomarkers, infection agents, and single nucleic polymorphisms (Frank, 2010). The assay provides highly sensitive and repeatable target detection with fast and simple signal reading, supporting that obelin is a reporter of choice.

To provide specificity to the binding assay, the label must contain a recognition element able to bind to the target with high affinity (Fig. 1). Usually, this element is an antibody or a hapten binding protein (e.g., in the case of streptavidinbiotin interaction). Relatively new biospecific molecules are aptamers, single-stranded DNA or RNA oligonucleotides (20-80 bases long) that fold into certain structures, exhibiting high specificity when binding to the target of interest. In the assay, aptamers function in a similar way to antibodies but successfully compete with them because aptamers are easily synthesized chemically (no animals needed) and can be selected for almost any target, including those that have low molecular weight and are toxic or nonimmunogenic. Due to these advantages, aptamers are becoming increasingly popular as biospecific elements in a number of biomedical analytical systems (Zhou et al., 2014). There are many methods (e.g., ultrafiltration, gel and capillary electrophoresis, HPLC, circular dichroism, and surface plasmon resonance) used to develop and characterize novel aptamers, which is usually a complicated and timeconsuming process. In this study, we consider a novel, rapid and simple method for aptamer development based on the obelin bioluminescent signal. Additionally, the paper describes several

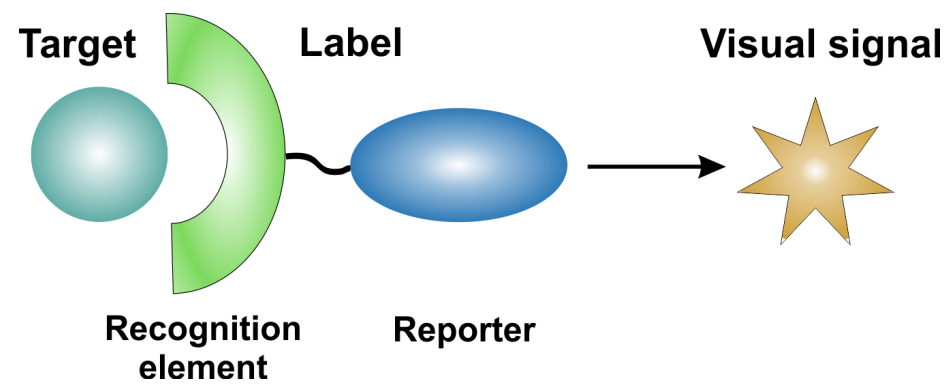

Fig. 1. General scheme for binding analysis 
examples showing successful application of the developed bioluminescent binding microassay for examining clinical samples.

\section{Bioluminescent solid-phase assay for aptamer development}

Usually, aptamers bound to the target of interest are obtained from large synthetic random libraries $\left(10^{14}-10^{15}\right.$ sequences $)$ through the systematic evolution of ligands by exponential enrichment (SELEX) procedure (Fig. 2). The process of aptamer selection includes several rounds of the repeating steps: incubation with the target (unbound material discarded), dissociation of bound oligonucleotides and their amplification.

A novel approach to monitor the course of selection based on the $\mathrm{Ca}^{2+}$-regulated photoprotein obelin was proposed by Krasitskaya et al. (Institute of Biophysics, SB RAS). The general scheme of the analysis is presented in Fig. 3a. With the approach applied, DNA aptamers to the cardiac marker troponin I and RNA aptamers to hemoglobins (general and glycated) (Davydova et al., 2019) and obelin (Krasitskaya et al., 2018) were developed within a short period of time and at relatively low cost. Fig. 3b-d shows the results on the library enrichment during the selection of the affine aptamers. Evaluation of individual aptamers' affinity by the bioluminescent solidphase assay is shown in Fig. 3e-g. Using the assay data, the saturation curves were obtained, and the dissociation constants of aptamer-corresponding target complexes were calculated.

The assay requires $1.5-2 \mathrm{~h}$; incubations are the longest stages of this analysis, while the measurement of the bioluminescent signal requires 3 to 5 seconds. The high sensitivity of obelin-based labels enables aptamer affinity within a low concentration range to be studied.

\section{Bioluminescent DNA aptamer-based solid-phase microassay for lung tumor element detection in plasma}

(Bashmakova et al., 2019, 2019a)

According to statistical data, lung cancer is a leading cause of cancer-related deaths worldwide. Despite the variety of screening methods used, many patients with this type of cancer begin treatment at stages 3 or 4 , when the tumor is no longer responsive to current therapies. Therefore, early clinical screening for premetastatic malignant tumors is highly important. A promising tool for better lung cancer screening and monitoring is evaluation and enumeration of circulating tumor elements (e.g., cells, cell debris, microemboli) in blood. Recently, a group of 10 DNA aptamers specific to

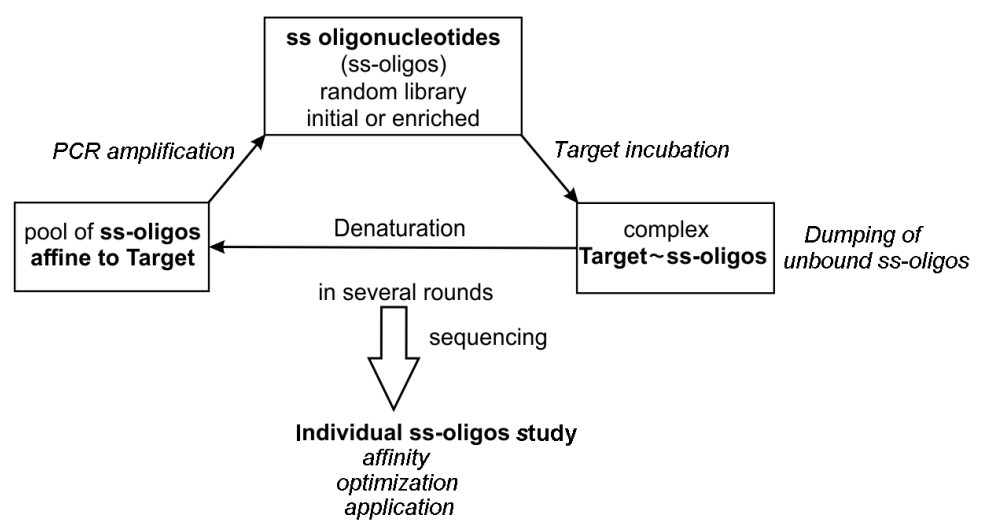

Fig. 2. General scheme for aptamer selection and study 

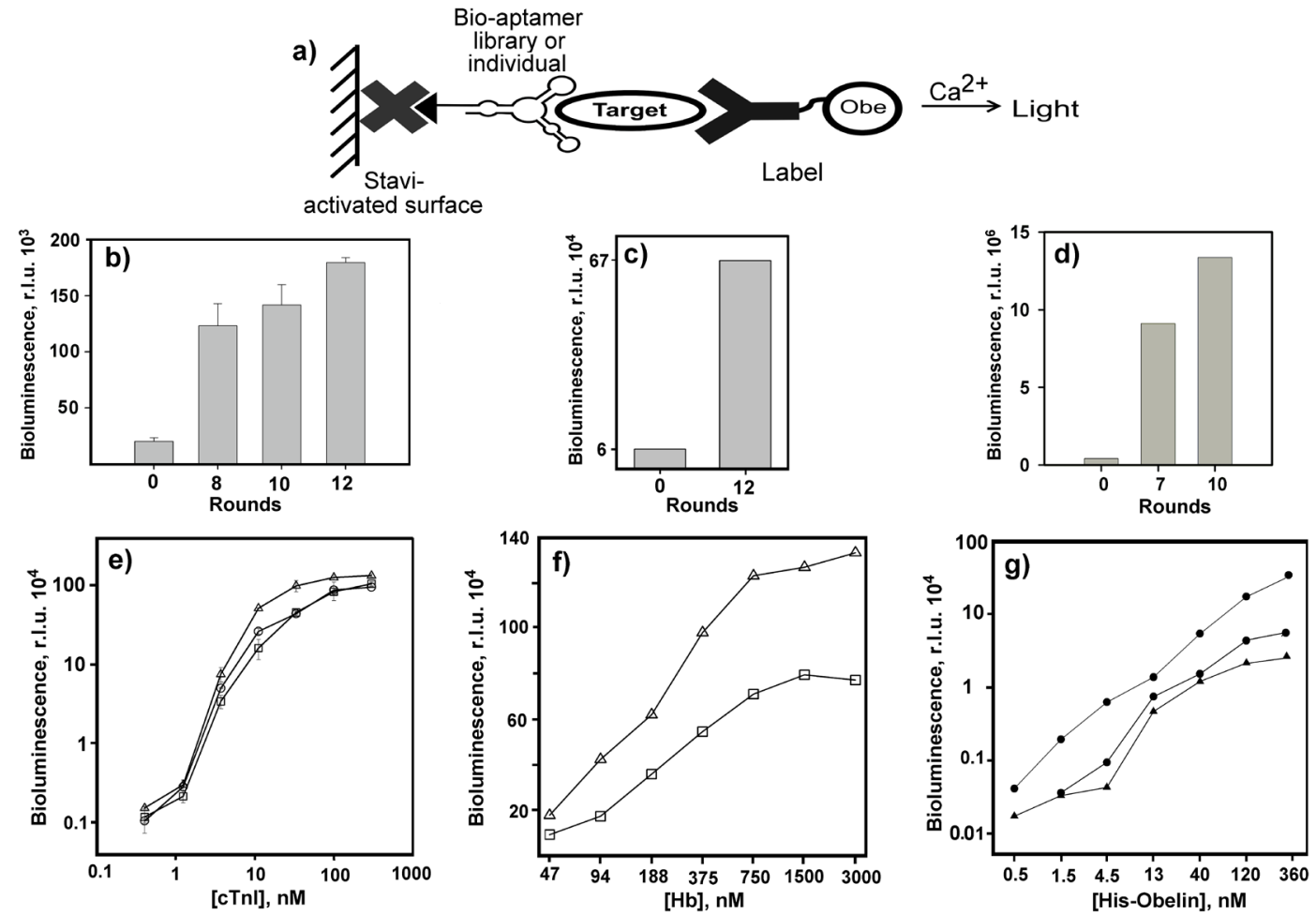

Fig. 3. Bioluminescent assay for aptamer development. Scheme of the assay (a); analyses of library enrichment (b-d) and affinity of individual aptamers (e-g) to the targets: cardiac troponin I (cTnI), hemoglobin (Hb), hexahistidine-obelin (His-Obelin). Stavi - streptavidin, Label - conjugate obelin-biospecific molecule

lung adenocarcinoma postoperative tissues was selected. Fluorescently labeled aptamers from this group, LC-17 and LC-18, were successfully applied to detect blood circulating tumor cells in patients with lung adenocarcinoma using confocal fluorescence microscopy (Zamay et al., 2015) and to histologically examine lung adenocarcinoma (Zamay et al., 2017). These 80-base aptamers show high affinity for postoperative lung tissue $(\mathrm{kd}=14 \mathrm{nM}$ and $38 \mathrm{nM}$, respectively) (Zamay et al., 2015) and are specific to different ligands. This property enabled us to propose a sandwich-type solidphase analysis of lung tumor elements in plasma using these aptamers as biospecific recognition elements and the photoprotein obelin as a signal element (Fig. 4a). This analysis is notably simple and fast compared to confocal fluorescence microscopy.
The surface of magnetic microspherical particles activated by aptamer LC-17 was used to capture and accumulate the targets. Aptamer LC-18 forms a sandwich-type complex, which is detected using obelin bioluminescence. For complex connections, the same oligonucleotide complementary to the 5' terminus of both aptamers labeled with biotin or obelin molecules was used. In this study, we note that aptamers share technological 20-base terminal fragments, whereas their central 40-base part is variable and usually defines aptamer affinity. Thus, the scheme includes two universal connectors: biotinylated oligonucleotide to form the analytical complex on the surface and the same oligonucleotide conjugated with obelin to detect the complex through a bioluminescent signal. This approach enables the use of any aptamer to any target if they share the same technological 

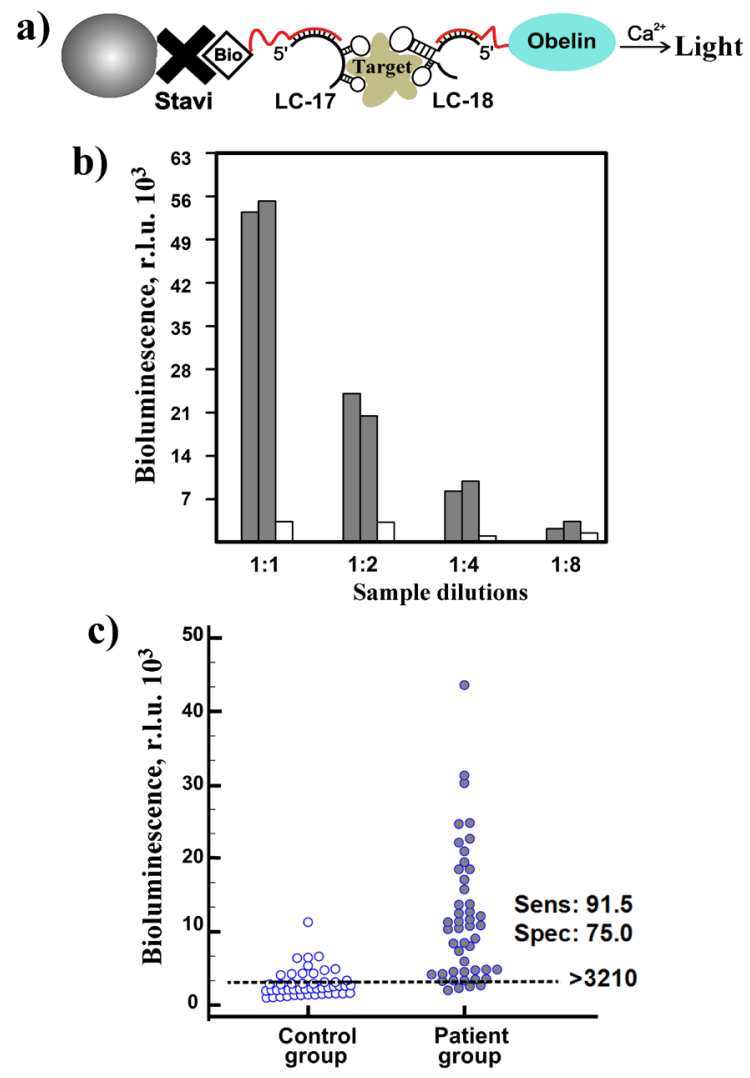

Fig. 4. Bioluminescent DNA aptamer-based solid-phase microassay for lung tumor element detection in plasma (a). Proof of the assay principle using two clinical (gray columns) and control plasma samples (b). Plasma sampling of patients and controls (c)

20-base terminal fragments (Bashmakova et al., 2019a).

Control experiments on model samples prepared from postoperative cancer and healthy lung tissues prove the approach to be applicable. Evidently, the bioluminescent signal decreases in diluted cancer samples and remains at a constantly low level in healthy lung tissue samples (Fig. 4b).

Next, 50 clinical plasma samples provided by the Krasnoyarsk Regional Clinical Oncology Center, named after A.I. Kryzhanovsky, were tested. The samples were collected prior to tumor resection surgery, and lung cancer diagnosis was histologically confirmed after surgery. The control group contained 48 samples collected from healthy donors in terms of lung cancer.
The results of the bioluminescent aptamer-based assay in plasma samples from patient and control groups are shown in Fig. 4c. Elevated signal levels in lung cancer patients were statistically significant $(\mathrm{p}<0.001)$. The chosen threshold value as the clinical decision limit offers an assay sensitivity of $91.5 \%$ and a specificity of $75 \%$. In this study, there were 10 cases at the first stage of cancer (the tumor is found in the lung but has not spread outside of it), 12 cases at the second stage, 18 at the third stage, and 7 cases at the fourth stage (cancer has spread to the lung, into the area around the lung or to distant organs). The signals from samples at different stages were compared using the Kruskal-Wallis test. No significant differences between the groups ( $p>0.05)$ were shown. Satisfactory results were obtained at the 
early stage of detection: the assay was able to reveal 8 out of 10 cases at the first stage of cancer and 11 out of 12 cases at the second stage. For the late cancer stages, the assay detected 17 out of 18 cases at the third stage of cancer and all the cases at the fourth stage.

Thus, the study demonstrates the potential of the bioluminescent assay involving aptamers as sensory elements for lung cancer detection and monitoring.

\section{Assay of anti-MBP autoantibodies associated with multiple sclerosis}

(Krasitskaya et al., 2019)

Multiple sclerosis (MS) is a chronic autoimmune-mediated disease of the central nervous system, usually associated with varying degrees of progressive disability. The initial and precise etiology of this disease has not been determined and is probably multifactorial. In addition, the course of the disease is highly variable and difficult to predict. Early diagnosis and timely treatment may decelerate disease progression and improve patients' lives. Today, MS diagnosis requires several diagnostic tests, including magnetic resonance imaging (MRI) and cerebrospinal fluid analysis, which are expensive, time-consuming and fraught with adverse effects. Pathogenic autoantibodies to myelin basic protein (anti-MBP) were first reported in 1980 (Panitch et al., 1980). It was ascertained that anti-MBP autoantibodies found in the sera of MS patients possess proteolytic activity and thus contribute to demyelination and disease pathogenesis in MS patients. These autoantibodies are believed to be good candidate biomarkers for diagnosing MS and monitoring disease activity (e.g., see the review Comabella, Montalban, 2014). The most important analytical problem facing this analysis is a low content (not more than 1\%) of anti-MBP autoantibodies compared to the total antibodies in sera.
Several modified RNA aptamers with high affinity $\left(K_{D}\right.$ values of approximately 3-7 $\mathrm{nM}$ ) to anti-MBP autoantibodies have been recently obtained (Krasitskaya et al., 2019; Vorobjeva et al., 2014). To provide RNA resistance to ribonuclease cleavage, all pyrimidines in their sequences were replaced with 2'-fluoro analogues.

Based on these aptamers and obelin, a bioluminescent solid-phase sandwich assay for the pathogenic anti-MBP antibodies was developed (Fig. 5). One aptamer (Apt 12-2b, Fig. 5a) was adsorbed on the microwell surface and "worked" on the target capturing, whereas the other aptamer (Apt 2-9c) preconjugated with obelin was applied as a specific bioluminescent probe to reveal the complex. The assay was first tested on model samples of $\mathrm{hIgG}$ at a constant concentration $(1.5 \mathrm{mg} / \mathrm{mL})$ spiked with anti-MBP autoantibodies (Fig. 5b). The analysis revealed a relative content of pathogenic autoantibodies up to $0.15 \%$ of total $\mathrm{hIgG}$. Using the assay conditions determined in model experiments, samples from MSdiagnosed patients (91) and non-MS donors (81) were analyzed. A statistical analysis of the results showed a $63.7 \%$ sensitivity and a $94.2 \%$ specificity of the assay developed (Fig. 5c).

The calculated AUC value of 0.87 demonstrates a statistically significant $(p<0.001)$ difference between the two groups under study. The negative predictive value (NPV) of $96.3 \%$ represents the number of patients with negative test results who do not have the disease. The positive predictive value (PPV) of $52 \%$ represents the number of patients with positive test results who have the disease. Although the majority of patients $(82.4 \%)$ were of relapsing-remitting subtype, this group was heterogeneous regarding such factors as the history of the disease and the therapy used. Therefore, further investigations are needed to consider the relationship between antiMBP antibody levels and such factors as disease 

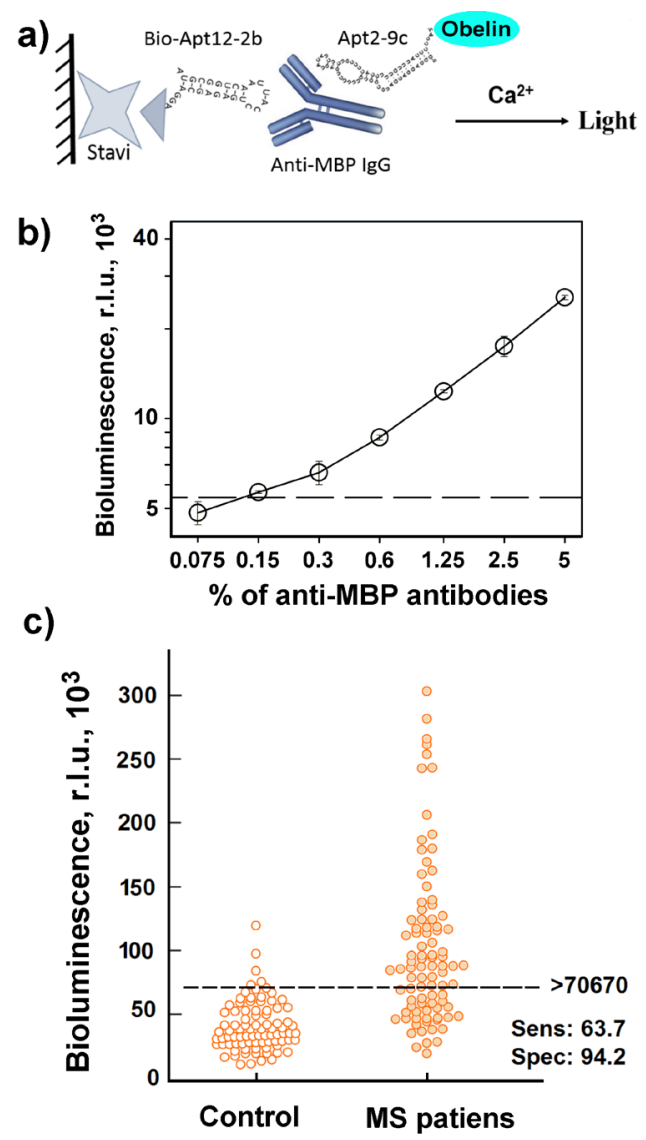

Fig. 5. Bioluminescent solid-phase assay of anti-MBP autoantibodies associated with multiple sclerosis (a). Assay of artificial sera (b). MS-patients' and controls' sera sampling (c)

stage and therapy. The analysis developed in this study can be a useful tool for clarifying many issues related to the emergence, development and treatment of this disease.

\section{Conclusion}

Modern analytical technologies based on aptamers, that is, biospecific molecules that can be obtained by chemical synthesis, easily modified and stored for a long time, have opened considerable avenues for researchers to create methods for identifying novel diagnostically important targets. Using bioluminescent reporters ensures a high-sensitivity analysis. Taken together, these factors can promote early diagnosis of the disease, which significantly affects treatment success. The results of the preliminary experiments described in this report demonstrate the potential of developing new analytical approaches involving aptamer sensors and bioluminescent reporters.

\section{Acknowledgments}

This work was supported by the Russian Foundation for Basic Research (RFBR) under grant no. 18-38-00531. 


\section{References}

Bashmakova E.E., Krasitskaya V.V., Zamay G.S., Zamay T.N., Frank L.A. (2019) Bioluminescent aptamer-based solid-phase microassay to detect lung tumor cells in plasma. Talanta, 199: 674-678

Bashmakova E.E., Frank L.A., Krasitskaya V.V. (2019a) Method of identifying targets associated with a specific diagnosis in the blood of patients based on DNA aptamers. Patent of RF (2019) No. 2685936

Comabella M., Montalban X. (2014) Body fluid biomarkers in multiple sclerosis. Lancet Neurology, 13(1): $113-126$

Davydova A., Vorobyeva M., Bashmakova E., Vorobjev P., Krasheninina O., Tupikin A., Kabilov M., Krasitskaya V., Frank L., Venyaminova A. (2019) Development and characterization of novel 2'-F-RNA aptamers specific to human total and glycated hemoglobins. Analytical Biochemistry, 570: $43-50$

Frank L.A. (2010) $\mathrm{Ca}^{2+}$-regulated photoproteins: effective immunoassay reporters. Sensors, 10(12): $11287-11300$

Krasitskaya V.V., Davydova A.S., Vorobyeva M.A., Frank L.A. (2018) The $\mathrm{Ca}^{2+}$-regulated photoproteinobelin as a target for the RNA aptamer selection. Russian Journal of Bioorganic Chemistry, 44(3): 296-301

Krasitskaya V.V., Chaukina V.V., Abroskina M.V., Vorobyeva M.A., Ilminskaya A.A., Kabilov M., Prokopenko S.V., Nevinsky G.A., Venyaminova A.G., Frank L.A. (2019) Bioluminescent aptamerbased sandwich-type assay of anti-MBP autoantibodies associated with multiple sclerosis. Analytica Chimica Acta, 1064: 112-118

Panitch H.S., Hooper C.J., Johnson K.P. (1980) CSF antibody to myelin basic protein - measurement in patients with multiple-sclerosis and subacute sclerosing panencephalitis. Archives of Neurology, 37(4): 206-209

Vorobjeva M.A., Krasitskaya V.V., Fokina A.A., Timoshenko V.V., Nevinsky G.A., Venyaminova A.G., Frank L.A. (2014) RNA aptamer against autoantibodies associated with multiple sclerosis and bioluminescent detection probe on its basis. Analytical Chemistry, 86(5): 2590-2594

Zamay G.S., Kolovskaya O.S., Zamay T.N., Glazyrin Y.E., Krat A.V., Zubkova O., Spivak E., Wehbe M., Gargaun A., Muharemagic D., Komarova M., Grigorieva V., Savchenko A., Modestov A.A., Berezovski M.V., Zamay A.S. (2015) Aptamers selected to postoperative lung adenocarcinoma detect circulating tumor cells in human blood. Molecular Therapy, 23(9): 1486-1496

Zamay G.S., Ivanchenko T.I., Zamay T.N., Grigorieva V.L., Glazyrin Y.E., Kolovskaya O.S., Garanzha I.V., Barinov A.A., Krat A.V., Mironov G.G., Gargaun A., Veprintsev D.V., Bekuzarov S.S., Kirichenko A.K., Zukov R.A., Petrova M.M., Modestov A.A., Berezovski M.V., Zamay A.S. (2017) DNA Aptamers for the characterization of histological structure of lung adenocarcinoma. Molecular Therapy - Nucleic Acids, 6: 150-162

Zhou W., Huang P.-J.J., Ding J., Liu J. (2014) Aptamer-based biosensors for biomedical diagnostics. Analyst, 139(11): 2627-2640 